\title{
REVISED ESforRPD2: Expert System for Rice Plant Disease
}

\section{Diagnosis [version 2; peer review: 1 approved, 1 approved}

\section{with reservations]}

\author{
Fahrul Agus (iD), Muh. Ihsan1, Dyna Marisa Khairina1, \\ Krishna Purnawan Candra(iD2 \\ ${ }^{1}$ GIS and Environment Modelling Lab. CSIT, Mulawarman University, Samarinda, East Kalimantan, 75242, Indonesia \\ ${ }^{2}$ Department of Agricultural Product Technology, Faculty of Agriculture, Mulawarman University, Samarinda, 75123, Indonesia
}

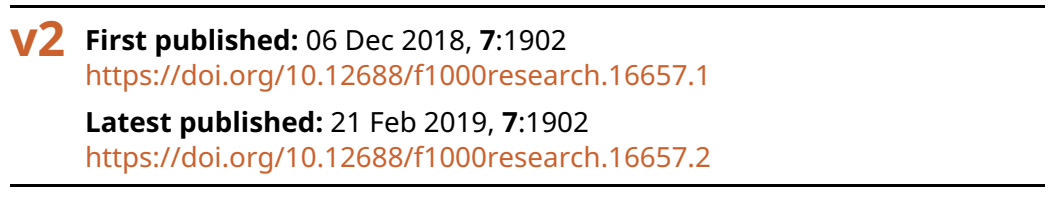

\section{Abstract}

One of the factors causing rice production disturbance in Indonesia is that farmers lack knowledge of early symptoms of rice plant diseases. These diseases are increasingly rampant because of the lack of experts. This study aimed to overcome this problem by providing an Expert System that helps farmers to make an early diagnosis of rice plant diseases.

Data of rice plant pests and diseases in 2016 were taken from Samarinda, East Kalimantan, Indonesia using an in-depth survey, and rice experts from the Department of Food Crops and Horticulture of East Kalimantan Province were recruited for the project. The Expert System for Rice Plant Disease Diagnosis, ESforRPD2, was developed based on the pest and disease experiences of the rice experts and uses a Waterfall Paradigm and Unified Modeling Language. This Expert System can detect 48 symptoms and 8 types of diseases of rice plants from 16 data tests with a sensitivity of $87.5 \%$.

ESforRPD2 is available in Indonesian at

http://esforrpd2.blog.unmul.ac.id

\section{Keywords}

Expert System, Rice Plant Disease, Waterfall, Unified Modelling Language

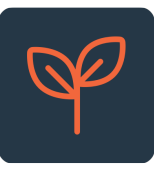

This article is included in the Agriculture, Food and Nutrition gateway.

Open Peer Review
Approval Status
version 2
(revision)
21 Feb 2019
06 Dec 2018
...............................................................................
1. Yi Fang (iD), University of Georgia, Athens,
USA
2. Marimin Marimin, IPB University (Bogor
Agricultural University), Bogor, Indonesia
Any reports and responses or comments on the
article can be found at the end of the article.


This article is included in the ICTROPS 2018

collection.

Corresponding author: Fahrul Agus (fahrulagus@unmul.ac.id)

Author roles: Agus F: Conceptualization, Funding Acquisition, Supervision, Writing - Original Draft Preparation, Writing - Review \& Editing; Ihsan M: Data Curation, Formal Analysis, Writing - Original Draft Preparation; Marisa Khairina D: Supervision; Candra KP:

Writing - Review \& Editing

Competing interests: No competing interests were disclosed.

Grant information: The author(s) declared that no grants were involved in supporting this work.

Copyright: @ 2019 Agus F et al. This is an open access article distributed under the terms of the Creative Commons Attribution License, which permits unrestricted use, distribution, and reproduction in any medium, provided the original work is properly cited. Data associated with the article are available under the terms of the Creative Commons Zero "No rights reserved" data waiver (CC0 1.0 Public domain dedication).

How to cite this article: Agus F, Ihsan M, Marisa Khairina D and Candra KP. ESforRPD2: Expert System for Rice Plant Disease Diagnosis [version 2; peer review: 1 approved, 1 approved with reservations] F1000Research 2019, 7:1902

https://doi.org/10.12688/f1000research.16657.2

First published: 06 Dec 2018, 7:1902 https://doi.org/10.12688/f1000research.16657.1 


\section{REVISED Amendments from Version 1}

- We corrected some typos (Abstract: 'Modelling' change to 'Modeling')

- We have changed the term of 'accuracy' to 'sensitivity' and added the explanation that the ES is specific to rice plant diseases diagnosis.

- We corrected some typos in the abstract and Table 1.

- We also agree with the comment from Yi Fang to change some sentences, i.e.

o "is the lack of knowledge of farmers on early symptoms..." changed to "is that farmers lack knowledge of early symptoms..." in the Abstract

o "accuracy of $87.5 \%$ " change "sensitivity of $87.5 \%$ " in the Abstract

o "...education, and business, including agriculture, problems" changed to "....education, business, and agriculture problems."

- We added 'was' to the sentence "Waterfall paradigm was applied in designing this ES"

- We have changed the term of 'accuracy' to 'sensitivity' in the sentence of "In this case test, the ES gave the accuracy of disease type detection of $91 \%$ " changed to "In this case test, the ES gave the sensitivity of disease type detection of $91 \% "$

See referee reports

\section{Introduction}

Correct diagnosis of symptoms in rice plant diseases, caused by bacteria, nematodes, fungi, phythoplasmal and viruses ${ }^{1-4}$, is very critical in supporting the productivity of rice plants. However, many regions in Indonesia have a huge problem because of a limited number of rice plant pathologists. The large plantation area of rice plants is also a problem due to logistical issues when visiting these sites, leading to difficulty obtaining disease evidence.

Along with other rapid technological developments, a technology known as Expert System $(\mathrm{ES})^{5-8}$ has been developed to solve health $^{9-12}$, education ${ }^{13}$, business ${ }^{14}$, and agriculture ${ }^{15,16}$, problems. ES is usually designed for a specific condition, i.e. variables of climate in cases of agriculture. This article proposes a new software based on ES for the diagnosis of disease in rice plants in the Samarinda region, Indonesia. Waterfall Paradigm was applied in designing this ES. The prototype, Expert System for Rice Plant Disease Diagnosis (ESforRPD2) is available at: http:// esforrpd2.blog.unmul.ac.id.

\section{Methods}

\section{Data collection and ES development}

The ES of rice plant disease diagnosis was designed to help farmers and agricultural officials to diagnose rice plant diseases occurring in the Samarinda region, East Kalimantan province, Indonesia. Rice plant experts were recruited from the Seed Technology Development Division at the Department of Food Crops and Horticulture of East Kalimantan Province and from the Department of Agro-eco-technology of Agricultural Faculty of Mulawarman University (one expert from each). The experts were the primary source for information on rice plant symptoms and diseases. The two rice plant experts have experience in diagnosing rice plant disease in the region of East Kalimantan Province for 20 years. Symptoms and diseases specific for rice plant and their relationships (and their ranked importance) were derived from the experts by questionnaire (Supplementary File 1). This allows the ES to be specific for rice plant diseases diagnosis. This information was then used to construct the knowledge base for building the ES software.

The ES software was developed using the Waterfall paradigm as recommended by Sommerville ${ }^{17}$ using five stages, i.e. (i) planning and requirement, (ii) analysis and software design, (iii) implementation and unit testing, (iv) integration and (v) system testing and operation and maintenance. ES architecture consists of three parts, namely the user interface, the inference engine and the knowledge base as proposed by Lucas and van der Gaag? The user interface is used as a consulting interface in order to obtain knowledge and advice from the ES, which would be like consulting an expert. In this ES, the inference engine works as a consultation system in processing input data to build a diagnosis based on the knowledge base developed.

\section{Implementation}

The implementation of the ESforRPD2 application is based on Unified Modelling Language (Figure 1) as proposed by Sommerville ${ }^{17}$, which consists of use case diagrams, activity diagrams, and class diagrams.

We constructed two types of "Use case diagram", namely "Use case for user" consisting of four cases (Article, Consulting, Choose Symptoms and Consulting Result); and "Use case for expert" consisting of three cases (Symptoms, Diseases, and Relation). The use case describes the functions of the ES interacting with user and expert. The activity diagram illustrates the flow of various activities being designed in the ES, i.e. how the flow starts, the decision that might occur, and the flow end. The activity diagram also describes parallel processes that might occur in some executions. In this ES, we build four data stores (Expert, Symptoms, Relation, and Diagnosis) in the class diagram. The ESforRPD2 application uses four datasets, namely disease- and symptoms-data, knowledge base, and symptomsdisease-weight relationships table (Dataset 2). The construction of decision trees and forward-chaining tracing for diagnosing of rice plant diseases in the ES is shown in Figure 2.

ESforRPD2 is the first version of ES (only in Indonesian) to make it user-friendly for Indonesian users. Users use a consultation page to choose the symptoms of the rice plant. The ES performs the calculation process to obtain the trust level using the Dempster-Shafer method ${ }^{18}$. The user page (Figure 3a) is the main web page for users without logging in. In the user page, there is also a home menu that displays articles about ES, rice plant diseases, and the Dempster-Shafer method. The consultation page starts the user consultation about the disease of rice plants (Figure 3b). The ES will provide an output as a display showing the symptoms, diagnosis of disease and the confidence level (Figure 3c). 
a

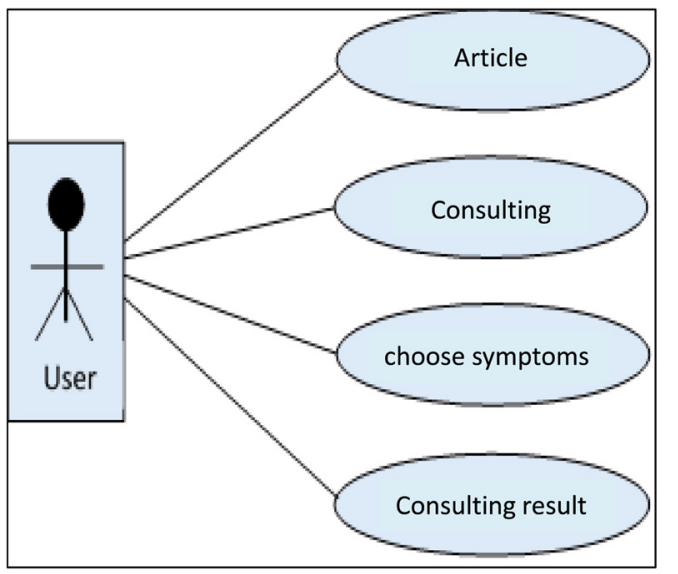

b

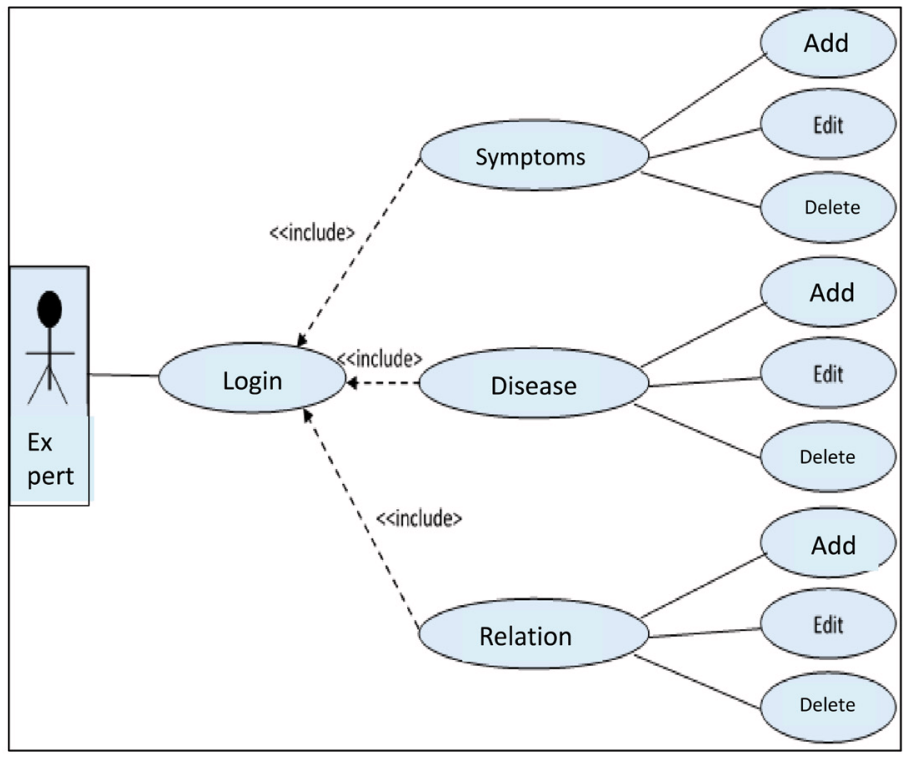

Figure 1. a. Use case diagram of user. b. Use case diagram of expert.



Figure 1c. Activity diagram of ESforRPD2 system application. 


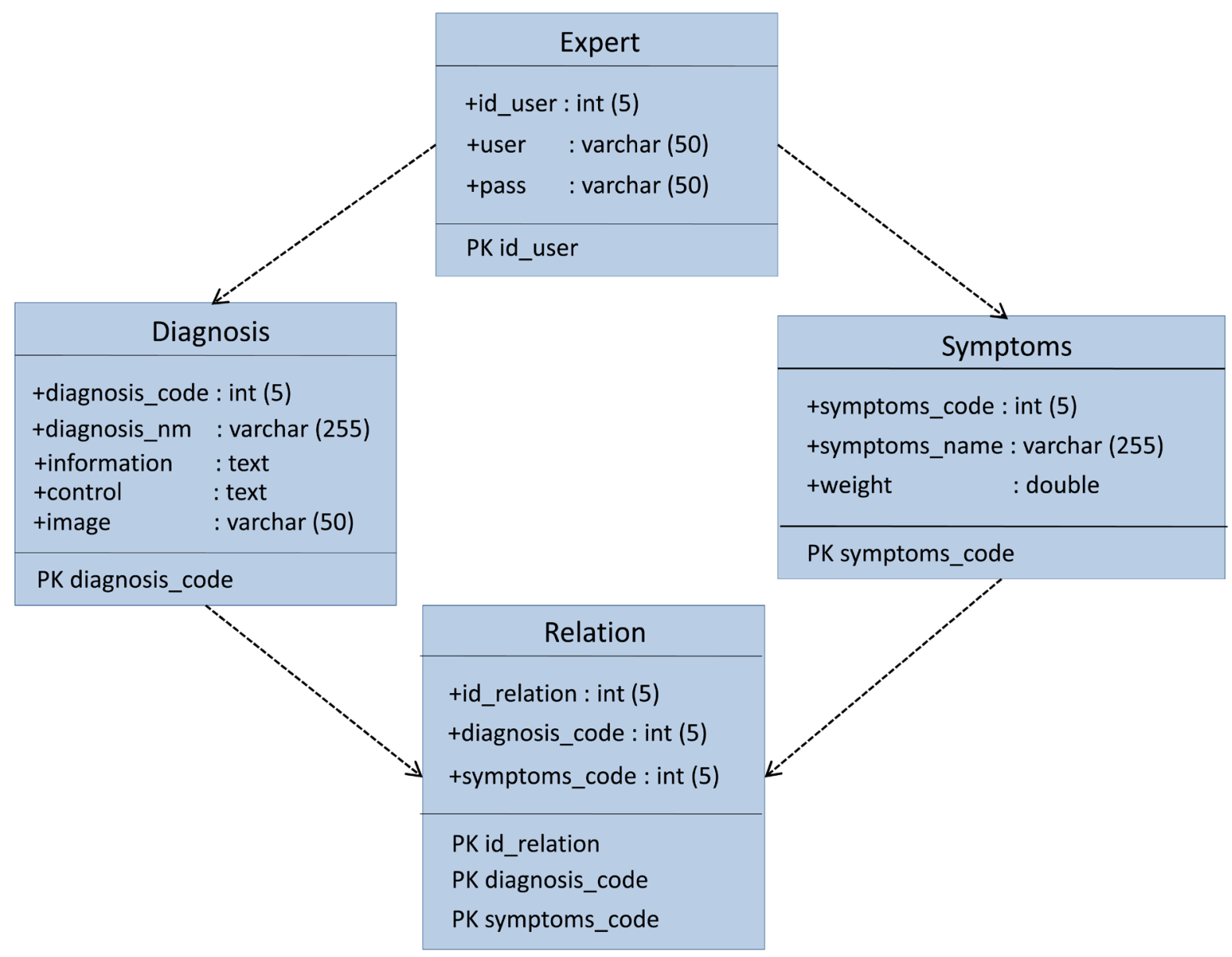

Figure 1d. Class diagram of ESforRPD2 system application.

\section{Operation}

The ESforRPD2 application is developed using CPU with specifications of Intel Core i3, 4GB RAM, and 300GB HDD. The same specification of CPU is needed to operate this application.

\section{Uses case}

The ESforRPD2 application was tested applying symptom-data inputs by clicking the symptoms selected (Figure 5b). In a single test using the case of four symptom-data inputs selected, namely (i) Spots on leaf midrib, (ii) Little spots are dark brown or slightly purple rounded shape, (iii) Spots on oval-shaped leaves and evenly distributed on the leaf surface, (iv) The size of spots is $2-10 \mathrm{~mm}$ long and $1 \mathrm{~mm}$ wide, a display of diagnosis page (Figure 3c) will appear following clicking of the "submit diagnose" button. The diagnosis page shows the confidence level. In this case test, the ES gave the sensitivity of disease type detection of $91 \%$.

16 tests in row were conducted using randomly selected symptoms by user in the ES. The results were approved by the two experts.
In total, 14 diagnosis $(87.5 \%)$ of the 16 results showed by the ES were justified by the two experts (Table 1).

\section{Discussion}

The ESforRPD2 application is showing good reliability. By applying 16 tests, the ESforRPD2 showed a level of performance of $87.5 \%$ (Table 1) following justification to two rice plants diseases experts. The performance of the ESforRPD2 during validation was the expected high-performance level of plant diseases diagnosis by the expert system. This performance is much higher than the performance of ES for Chili pepper pest diagnosis invented by Agus et al. ${ }^{16}$. However other Expert System could show excellent performance of $98.38 \%{ }^{19}$, this evidence advice that the performance of ESforRPD2 could be improved in the next study.

Currently, ESforRPD2 has only been tested with data from the Samarinda region. In a future study, we will use data from other regions of East Kalimantan, which have the same climate (tropical rainforest) and soil character as the Samarinda region. In addition, we will test data from other regions in Indonesia, 


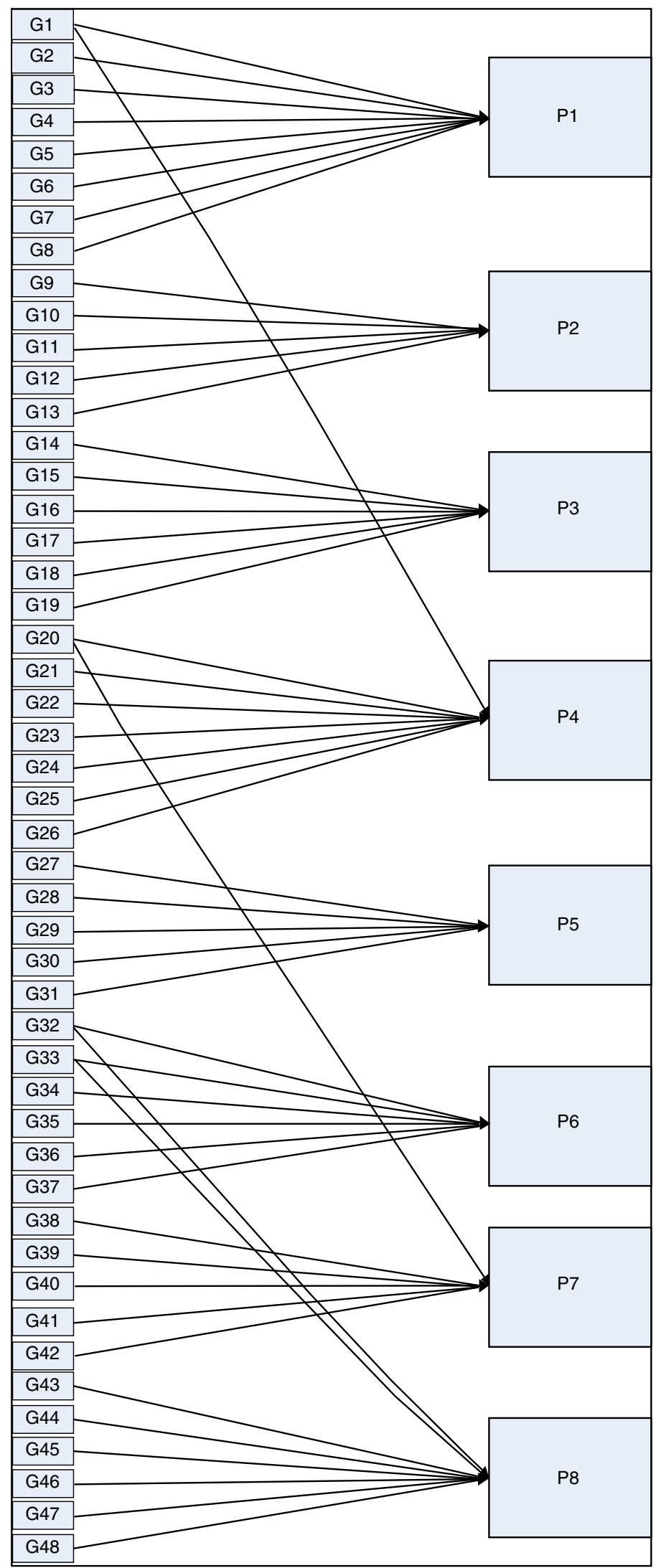

Figure 2. Decision tree and forward chaining tracing. 


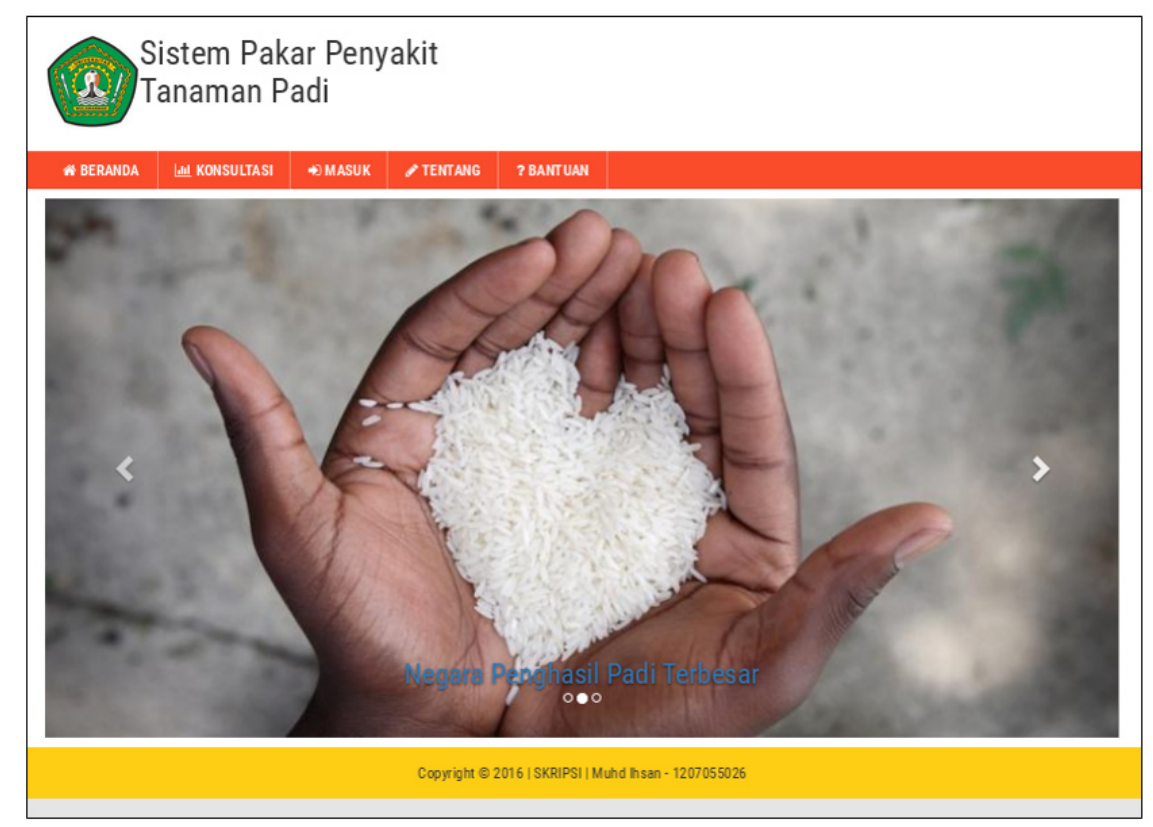

Figure 3a. User main page.

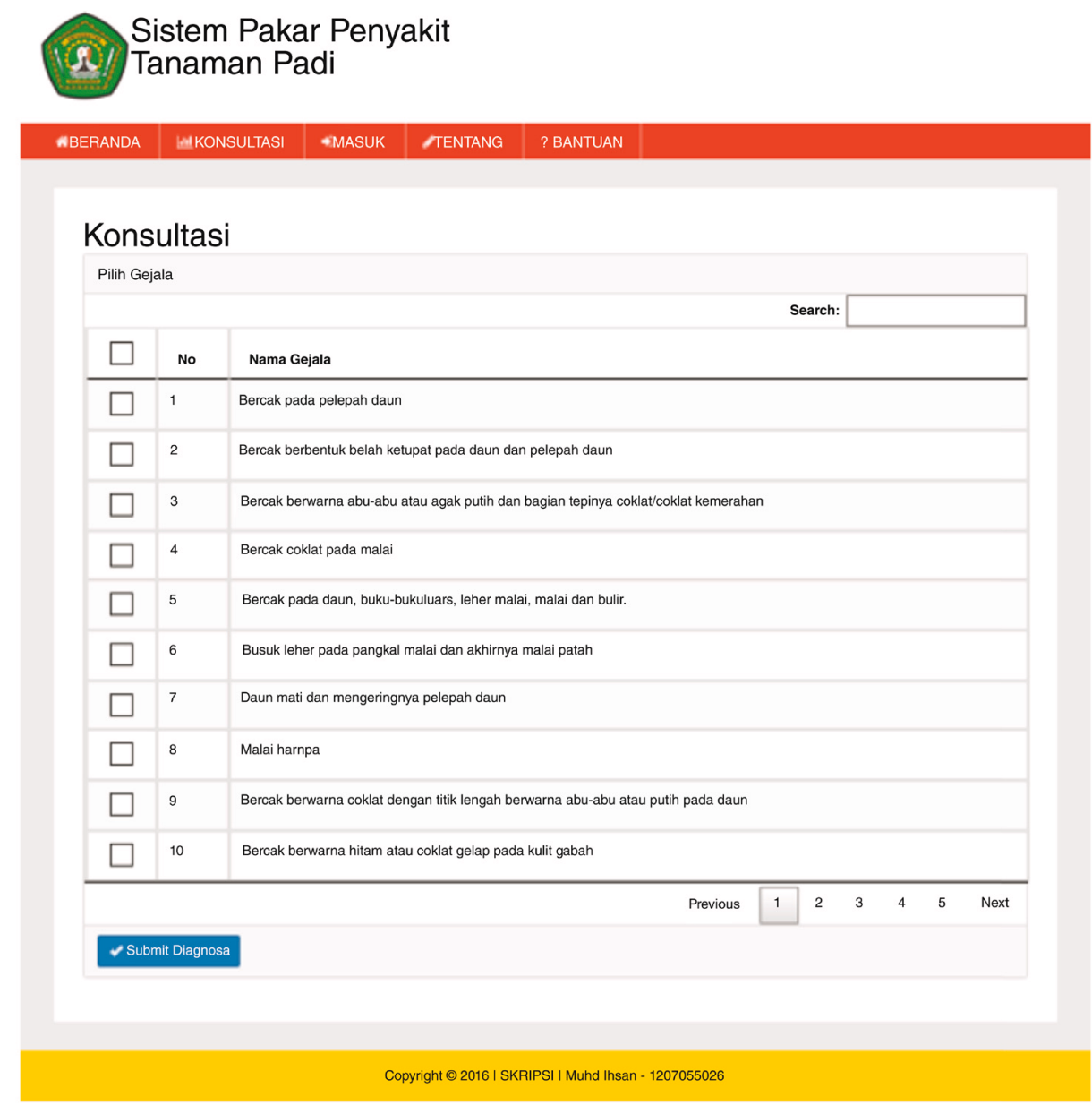

Figure $3 b$. Consultation page. 


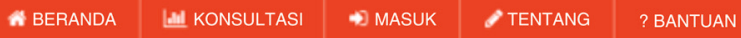

\section{Hasil Diagnosa}

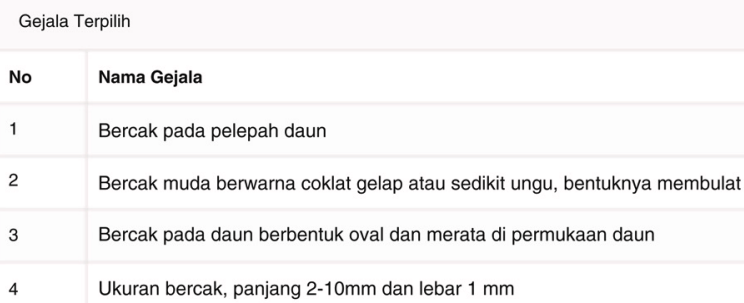

Berdasarkan gejala yang terpilih maka diagnosa paling akurat adalah :

Bercak Coklat/Brown Spot. (Helminthosporium oryzae/Drechslera oryzae)

\section{Dengan Tingkat Kepercayaan 91\%.}

Figure 3c. Diagnosis results page.

Table 1. System testing with expert justification.

\begin{tabular}{|c|l|l|l|}
\hline Test No. & Experts Justification (English/Indonesian) & \multicolumn{1}{|c|}{$\begin{array}{c}\text { Results Diagnosis of ESforRPD2 } \\
\text { (English/Indonesian) }\end{array}$} & Results \\
\hline 1 & Blast/Blas & Blast/Blast & Suitable \\
\hline 2 & Brown Spot (Bercak Coklat) & Brown Spot (Bercak Coklat) & Suitable \\
\hline 3 & Narrow Brown Spot (Bercak Coklat Sempit) & Narrow Brown Spot (Bercak Coklat Sempit) & Suitable \\
\hline 4 & Sheath Bligh (Hawar Pelepah) & Sheath Bligh (Hawar Pelepah) & Suitable \\
\hline 5 & False Smut (Noda Palsu/Gosong Palsu) & False Smut (Noda Palsu/Gosong Palsu) & Suitable \\
\hline 6 & Grassy Stunt (Kerdil Rumput) & Grassy Stunt (Kerdil Rumput) & Suitable \\
\hline 7 & Bacterial leaf blight (BLB-Kresek Hawar Daun) & Bacterial leaf blight (BLB-Kresek Hawar Daun) & Suitable \\
\hline 8 & Tungro (Tungro) & Tungro (Tungro) & Suitable \\
\hline 9 & Blast (Blas) & Blast (Blas) & Suitable \\
\hline 10 & Brown Spot (Bercak Coklat) & Brown Spot (Bercak Coklat) & Suitable \\
\hline 11 & Narrow Brown Spot (Bercak Coklat Sempit) & Blast/Blas & Unsuitable \\
\hline 12 & Sheath Bligh (Hawar Pelepah) & Blast/Blas & Unsuitable \\
\hline 13 & False Smut (Noda Palsu/Gosong Palsu) & False Smut (Noda Palsu/Gosong Palsu) & Suitable \\
\hline 14 & Grassy Stunt (Kerdil Rumput) & Grassy Stunt (Kerdil Rumput) & Suitable \\
\hline 15 & Bacterial leaf blight (BLB-Kresek Hawar Daun) & Bacterial leaf blight (BLB-Kresek Hawar Daun) & Suitable \\
\hline 16 & Tungro (Tungro) & Tungro (Tungro) & Suitable \\
\hline & & & \\
\hline
\end{tabular}


which have a different climate. Newbery et al. ${ }^{20}$ showed that different climate conditions affect symptoms of arable crop disease; therefore, the ESforRPD2 will need continuous evaluation because climate change effects ${ }^{21}$

\section{Consent}

Written informed consent was obtained from the two experts for participation in the study.

\section{Software availability}

Software application is available from: http://esforrpd2.blog. unmul.ac.id.

Source code: https://github.com/fahrulagus/paper.

Archived source code as at time of publication: https://doi. org/10.5281/zenodo. $1490641^{22}$

License: GNU GPL v3.0
Data availability

Underlying data

Zenodo: Knowledge base for rice plant disease diagnosis, https:// doi.org/10.5281/zenodo.1490658 23

Extended data

Zenodo: Dataset for rice plant diseases expert interview, http:// doi.org/10.5281/zenodo.195338324

Grant information

The author(s) declared that no grants were involved in supporting this work.

\section{Acknowledgements}

The authors are grateful to both experts in this research, the Rector of Mulawarman University and Islamic Development Bank Project.
1. Jagan Mohan K, Balasubramanian M, Palanivel S: Detection and Recognition of Diseases from Paddy Plant Leaf Images. Int J Comput Appl. 2016; 144(12) 34-41.

Publisher Full Text

2. Chapuis E, Besnard G, Andrianasetra S, et al.: First report of the root-knot nematode (Meloidogyne graminicola) in Madagascar rice fields. Australas Plant Dis Notes. 2016; 11(1): 32

Publisher Full Text

3. Qudsia H, Akhter M, Riaz A, et al:: Comparative Efficacy of Different Chemica Treatments for Paddy Blast, Brown Leaf Spot and Bacterial Leaf Blight Diseases in Rice (Oryza Sativa L.). Appl Microbiol Open Access. 2017; 3(3). Publisher Full Text

4. Kulmitra AK, Sahu N, Kumar VBS, et al:: In vitro evaluation of bio-agents against Pyricularia oryzae (Cav.) causing rice blast disease. Agric Sci Dig - A Res J. 2017; 37(3): 98-101. Publisher Full Text

5. Todd BS: An Introduction to Expert Systems. Issue 95, Oxford University Computing Laboratory, Programming Research Group; 1992. Reference Source

6. Turban E, Frenzel LE: Expert Systems and Applied Artificial Intelligence. Prentice Hall Professional Technical Reference; 1992. Reference Source

7. Lucas PJF, van der Gaag LC: Principles of Expert Systems. Amsterdam: Addison-Wesley; 1991.

Reference Source

8. Gaines BR: Designing Expert Systems for Usability. Knowl Creat Diffus Util. 1986; $1-40$.

Reference Source

9. Gudu J, Gichoya D, Nyongesa P, et al.: Development of a medical expert system as an expert knowledge sharing tool on diagnosis and treatment of hypertension in pregnancy. Int J Biosci Biochem Bioinforma. 2012; 2(5): 297-300. Publisher Full Text

10. Abu Naser SS, Ola AZA: An expert system for diagnosing eye diseases using clips. Theor Appl Inf Technol. 2008; 923-930. Reference Source

11. Ayangbekun OJ, Jimoh IA: Expert System for Diagnosis Neurodegenerative Diseases. Int J Comput Inf Technol. 2015; 4(4): 694-698. Reference Source

12. Ayangbekun OJ, Bankole FO: An Expert System for Diagnosis of Blood Disorder. Int J Comput Appl. 2014; 100(7): 975-8887.

Reference Source
13. Divayana DGH: Utilization of cse-ucla model in evaluating of digital library program based on expert system at universitas teknologi indonesia: A mode for evaluating of information technology-based education services. J Theor Appl Inf Technol. 2017; 95(15): 3585-3596. Reference Source

14. Arias-Aranda D, Castro JL, Navarro M, et al:: A fuzzy expert system for business management. Expert Syst Appl. 2010; 37(12): 7570-7580. Publisher Full Text

15. Ihsan M, Agus F, Khairina DM: Penerapan Metode Dempster Shafer Untuk Sistem Deteksi Penyakit Tanaman Padi. Prosiding Seminar Ilmu Komputer dan Teknologi Informasi. 2017; 2(1). Reference Source

16. Agus F, Wulandari HE, Astuti IF: Expert System With Certainty Factor For Early Diagnosis Of Red Chili Peppers Diseases. JAIS. 2017; 2(2): 52-66. Reference Source

17. Sommerville I: Software Engineering. 10th Edition. Pearson; 2016. Reference Source

18. Maseleno A, Mahmud Hasan M: Skin infection detection using Dempster-Shafer theory. In: 2012 International Conference on Informatics, Electronics and Vision, ICIEV 2012.2012. Publisher Full Text

19. Sabzi S, Abbaspour-Gilandeh Y, García-Mateos G: A fast and accurate expert system for weed identification in potato crops using metaheuristic algorithms. Comput Ind. 2018; 98: 80-89. Publisher Full Text

20. Newbery F, Qi A, Fitt BD: Modelling impacts of climate change on arable crop diseases: progress, challenges and applications. Curr Opin Plant Biol. 2016; 32 101-109.

PubMed Abstract | Publisher Full Tex

21. Xu C, Wu W, Ge Q: Impact assessment of climate change on rice yields using the ORYZA model in the Sichuan Basin, China. Int J Clim. 2018; 38(7): 2922-2939. Publisher Full Text

22. fahrulagus, Fajar Ml: fahrulagus/paper: ESforRPD2 (Version V.10). Zenodo. 2018 http://www.doi.org/10.5281/zenodo.1490641

23. Agus F, Ihsan M, Khairina DM, et al.: Knowledge base for rice plant disease diagnosis [Data set]. Zenodo. 2018 http://www.doi.org/10.5281/zenodo.1490658

24. Agus F, Ihsan M, Khairina DM, et al.: Dataset for rice plant diseases expert interview [Data set]. Zenodo. F1000Research. 2018. http://www.doi.org/10.5281/zenodo.1953383 


\section{Open Peer Review}

\section{Current Peer Review Status:}

\section{Version 2}

Reviewer Report 22 May 2020

https://doi.org/10.5256/f1000research.19990.r59359

(C) 2020 Marimin M. This is an open access peer review report distributed under the terms of the Creative Commons Attribution License, which permits unrestricted use, distribution, and reproduction in any medium, provided the original work is properly cited.

\section{Marimin Marimin}

Department of Agricultural Industrial Technology, Faculty of Agricultural Technology, IPB University (Bogor Agricultural University), Bogor, Indonesia

In the last section of abstract should be added that the system also provide suggestion for handling the identified disese.

The interface of the implemented system is in Indonesian, It will be better beside the Indonesian, it should be available also in English.

The data used is considered old, and only in one year, 2016. It will be better if new data were added and considered, such as in 2017, for better accuracy. Moreover, information on the experts contribute in the system development should be described, how many experts, expert qualification and the knowledge elicitation procedure should be described.

In Expert system development there two concerned, software development and knowledge based development. Waterfall model used for software development is reasonably described. However, the knowledge based development is not described.

The developed system used rube based which has drawback in maintenance difficulties due to the exponential grow of rules when some variables are added. Why not use fuzzy rule based or at least added in the discussion section for future enhancement?

Discussion on how the disease are determined and the suggestion are provided should be added in the discussion section.

Is the rationale for developing the new software tool clearly explained?

Yes

Is the description of the software tool technically sound?

Yes

Are sufficient details of the code, methods and analysis (if applicable) provided to allow replication of the software development and its use by others? 
Partly

Is sufficient information provided to allow interpretation of the expected output datasets and any results generated using the tool?

Partly

Are the conclusions about the tool and its performance adequately supported by the findings presented in the article?

Partly

Competing Interests: No competing interests were disclosed.

Reviewer Expertise: INtelligence decision support system and expert systems, Intelligence supply chain management.

I confirm that I have read this submission and believe that I have an appropriate level of expertise to confirm that it is of an acceptable scientific standard, however I have significant reservations, as outlined above.

Reviewer Report 01 March 2019

https://doi.org/10.5256/f1000research.19990.r44749

(C) 2019 Fang $Y$. This is an open access peer review report distributed under the terms of the Creative Commons Attribution License, which permits unrestricted use, distribution, and reproduction in any medium, provided the original work is properly cited.

\section{Yi Fang}

Nano Electrochemistry Laboratory, College of Engineering, University of Georgia, Athens, GA, USA

After the language revision and then using the correct terminologies, I agree that the manuscript should be indexed.

Is the rationale for developing the new software tool clearly explained?

Partly

Is the description of the software tool technically sound?

Partly

Are sufficient details of the code, methods and analysis (if applicable) provided to allow replication of the software development and its use by others?

Partly

Is sufficient information provided to allow interpretation of the expected output datasets and any results generated using the tool? 
Partly

Are the conclusions about the tool and its performance adequately supported by the findings presented in the article?

Partly

Competing Interests: No competing interests were disclosed.

Reviewer Expertise: electrochemistry, plant diseases, biosensors, sensor

I confirm that I have read this submission and believe that I have an appropriate level of expertise to confirm that it is of an acceptable scientific standard.

\section{Version 1}

Reviewer Report 24 January 2019

https://doi.org/10.5256/f1000research.18205.r43488

(C) 2019 Fang Y. This is an open access peer review report distributed under the terms of the Creative Commons Attribution License, which permits unrestricted use, distribution, and reproduction in any medium, provided the original work is properly cited.

\section{Yi Fang}

Nano Electrochemistry Laboratory, College of Engineering, University of Georgia, Athens, GA, USA

The author applied Expert System (ES) for rice plant disease and diagnosis; the background information and introduction is sufficient and well organized. The entire manuscript is also presented well. However, the author used the word "accuracy" which is not quite a scientific term. If "accuracy" is defined as sensitivity of the method, how about the specificity of the method? If a method has low specificity, it may not be able to solve the problem from false positive. For other comments, please see below:

Page 1: Change "is the lack of knowledge of farmers on early symptoms..." to "is that farmers lack of knowledge of early symptoms...".

Page 1: "accuracy of $87.5 \%$ " accuracy is not a scientific terminology, do you refer to sensitivity or specificity?

Page 3: change "... education, and business, including agriculture, problems" to "...education, business, and agriculture problems."

Page 3: please change to "Waterfall Paradigm was applied in designing this ES."

Page 5: "In this case test, the ES gave the accuracy of disease type detection of 91\%". Do you refer to sensitivity? Please also try to apply this comment to the other "accuracy" you mentioned in the manuscript. 
Is the rationale for developing the new software tool clearly explained?

Partly

Is the description of the software tool technically sound?

Yes

Are sufficient details of the code, methods and analysis (if applicable) provided to allow replication of the software development and its use by others?

Yes

Is sufficient information provided to allow interpretation of the expected output datasets and any results generated using the tool?

Yes

Are the conclusions about the tool and its performance adequately supported by the findings presented in the article?

Yes

Competing Interests: No competing interests were disclosed.

Reviewer Expertise: electrochemistry, plant diseases, biosensors, sensor

I confirm that I have read this submission and believe that I have an appropriate level of expertise to confirm that it is of an acceptable scientific standard, however I have significant reservations, as outlined above.

Author Response 12 Feb 2019

Fahrul Agus, Mulawarman University, Samarinda, Indonesia

We agree with your judgment regarding the term of accuracy. We meant the accuracy is the sensitivity, for that reason we change the term accuracy to sensitivity. Regarding the term of specificity, we explain that this system has high specificity for rice plants because all data used in constructing the algorithm were collected specifically for rice plant diseases.

Competing Interests: No competing interests were disclosed. 
The benefits of publishing with F1000Research:

- Your article is published within days, with no editorial bias

- You can publish traditional articles, null/negative results, case reports, data notes and more

- The peer review process is transparent and collaborative

- Your article is indexed in PubMed after passing peer review

- Dedicated customer support at every stage

For pre-submission enquiries, contact research@f1000.com 